\title{
Improving High-Level Thinking Skills in Students Through Powtoon-Based Animation Video Media
}

\author{
Fahni Rahmawati ${ }^{*}$, Zaka Hadikusuma Ramadan ${ }^{2}$ \\ ${ }^{1,2}$ Pendidikan Guru Sekolah Dasar, Universitas Islam Riau, Pekanbaru, Indonesia
}

\section{A R T I CLE I N F O}

Article history:

Received October 10, 2021

Revised October 11, 2021

Accepted November 12, 2021

Available onlineNovember 25, 2021

Kata Kunci:

Animasi, Powtoon, Berpikir Tingkat

Tinggi

Keywords:

Animation, Powtoon, Higher Order

Thinking

DOI:

https://dx.doi.org/10.23887/jet.v5i4 41037

\begin{abstract}
A B S T RA K
Siswa kurang mampu mengoptimalkan kemampuan berpikir tingkat tinggi. Masih banyak siswa yang bingung dalam mengerjakan soal yang berkaitan dengan kemampuan berpikir tingkat tinggi. Penelitian ini bertujuan untuk mengembangkan produk yang berbentuk media video animasi berbasis powtoon dan untuk menguji kefektifannya terhadap keterampilan berpikir tingkat tinggi peserta didik kelas III SD. Penelitian ini merupakan penelitian pengembangan (Research and Develpment). Rancangan penelitian ini menggunakan model ADDIE dan menggunakan desain pre-eksperiment one group pretest posttest design. Jenis data yang diambil dari pengembangan ini yaitu data kualitatif dan data kuantitatif. Teknik Pengumpulan Data terdiri dari tiga jenis yaitu pertama angket respon guru dan peserta didik, kedua lembar validasi pakar media, pakar materi dan pakar bahasa, ketiga soal tes dipergunakan untuk mengumpulkan data mengenai kekerampilan berpikir tingkat tinggi. Berdasarkan hasil penelitian dari pakar materi dengan total 97\%, pakar media debgan total 97\% dan ahli bahasa dengan total 86,25\% dan hasil total keselurahan 93,4\% menyimpulkan bahwa sangat valid digunakan sebagai media pembelajaran. Hasil analisis respon guru dengan total $99,33 \%$ dan peserta didik dengan total 87,25\% dan hasil total keselurahan 93,25\% menyimpulkan bahwa media praktis digunakan dalam kegiatan proses pembelajaran berlangsung. Berdasarkan hasil pengujian penelitian kelihatan dari perbedaan skor pretest dan posttest merupakan 060,435 dimana total skor pretest 19.57 dan total skor posttest adalah 80,00 kelihatan dari nilai t hitung adalah -48,195 dengan signifikansi $0,00<0,005 y a n g$ berarti HO ditolak dan Ha diterima. Jadi dapat menyimpulkan bahwa ada perbedaan skor keterampilan berpikir tingkat tinggi saat sebelum serta setelah pembelajaran memakai media video animasi berbasis powtoon.
\end{abstract}

\section{A B S T R A C T}

Students are less able to optimize higher-order thinking skills. There are still many students who are confused in working on problems related to higher thinking skills. This paper provides a template for preparing papers for electronic production of the Journal of Education Technology. A well-prepared abstract enables the reader to identify the basic content of a document quickly and accurately, to determine its relevance to their interests, and thus to decide whether to read the document in its entirety. The Abstract should be informative and completely self-explanatory, provide a clear statement of the problem, the proposed approach or solution, and point out major findings and conclusions. The Abstract should be 150 to 250 words in length. The abstract should be written in the past tense. Standard nomenclature should be used and abbreviations should be avoided. No literature should be cited. The keyword list provides the opportunity to add keywords, used by the indexing and abstracting services, in addition to those already present in the title. Judicious use of keywords may increase the ease with which interested parties can locate our article.

This is an open access article under the CC BY-SA license. Copyright (C) 2021 by Author. Published by Universitas Pendidikan Ganesha.

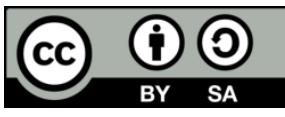

\section{INTRODUCTION}

The 21st-century educational paradigm emphasizes the ability of students to think critically, connect knowledge with the real world, understand data communication technology, and collaborate (Chalkiadaki, 2018; Gürsoy, 2021). From the 21st century, students must have critical thinking skills or solve problems (Almaiah et al., 2020; Sapeni \& Said, 2020; Wartono et al., 2018). Meanwhile, 21st-century education does not only require students to master material content but instead directs them to higher-order thinking skills (Perdana et al., 2017; Ratajczak, 2018). Higher-order thinking skills are a stage of thinking about the cognitive abilities of higher 
learners (Indah, 2020; Perdana et al., 2017). Higher-order thinking students can solve a problem, discuss a problem, and use students' knowledge in new situations (Ichsan et al., 2019; Turan \& Koç, 2018). According to Bloom's taxonomy, there are various high-level stages in analyzing, evaluating, and creating skills (Changwong et al., 2018; Zulfiani et al., 2020). so learning leads to analyzing, evaluating, and creating. Teachers are required to be creative and innovative in preparing learning materials to empower higher-order thinking skills (Hobri et al., 2018; Sugianti et al., 2018).

Based on the results of interviews with third-grade homeroom teachers at SDN 66 Pekanbaru, students are less able to optimize higher-order thinking skills. There are still many students who are confused in working on problems related to higher-order thinking skills. Students have not been able to connect the knowledge learned and implement it in real life (Acesta, 2020; Harta et al., 2020). It is because learning in schools is still monotonous and conventional. In education in schools, teachers generally only direct conventional materials, prioritize memorization skills and do not build students' creativity and problem-solving abilities rather than higher abilities (Khan \& Masood, 2015; Sari et al., 2020). They are learning that only focuses on the teacher or is monotonous and conventional so that students are more dominant in listening to the teacher (Rosalina \& Suhardi, 2020). Making students passive and the lack of variety in learning creates saturation in the learning process (Hamzah \& Mentari, 2017; Nuswowati et al., 2017). It is what must be avoided. One method to overcome monotonous and conventional education is an attractive educational media and utilize the results of technological advances to facilitate the learning process in terms of effectiveness and efficiency (Ani Rahmawati, Nur Lailatin Nisfah, 2019; Ariani, 2017).

The rapid growth of the current world of technology has created many internet-connected applications (Binali et al., 2021; Sugiarto, 2020). Teachers should strengthen these technological advances to help make learning activities successful in the world of learning (Khairunnisa, 2021; Samsudin et al., 2019). It is due to the influence of technology that extends to various fields of life, including education, so from this, it is because the progress of the learning world cannot run without the encouragement of technology (D. N. L. Laksana, 2020; Lu \& Wang, 2008). In this digital era, technological progress is proliferating in all fields of science (Bana, 2020; Mershad \& Wakim, 2018). It is indicated by the continued dependence of the learning world on technology in the activities of the educational process so that teachers innovate to support technology that is remarkably developed at this time. One example of technological progress in learning is video animation (L. Lin \& Li, 2018; Rahayuningsih, 2020). Animated video is a learning media that presents objects clearly so that they can understand difficult lessons. This animated video media unites audio and visual media to attract students' interest (Sanchez \& Weber, 2019; Zhang et al., 2020). Animated videos can attract students' attention in receiving educational material, informed by the teacher that it can be used to stimulate students' thoughts, feelings, interests, and desires (Kühl, 2021; H. Lin \& Chen, 2016). This media is packaged in a fun way to make the teaching process more enjoyable (Hanif, 2020; Koning et al., 2019). Animation is a technique that creates the illusion of continuous movement. The existence of animation can explain something difficult to explain concepts that can move and give the impression of life on learning videos (Amali et al., 2020; Kolomuc et al., 2012). One of the animated video applications that are often used as learning media is the Powtoon application.

Powtoon is a web application in which there are exciting animation features. The Powtoon application has various engaging animations that can become an exciting product (Kamza et al., 2021; Wulandari, 2020). The powtoon application can also design various animations according to critical needs (Hasbullah, 2018). The role of this portion of learning media can make students understand lessons faster and make students more enthusiastic about learning (I. Awalia et al., 2019; Lestari et al., 2018). Powtoon-based learning animation videos are cartoon animations filled with various learning materials. They are very suitable for educational media because they are exciting, funny, and suitable for elementary school children (Anjarsari et al., 2020; Izomi Awalia et al., 2019). The use of suitable and sufficient media is expected to overcome the limitations that exist in the learning process (Abdul Karim et al., 2020; Megawati \& Utami, 2020). Describing and launching abstract concepts can motivate learning, generate creativity in students, and think at higher levels. The findings of previous studies stated that animation could help students learn (L. Lin \& Li, 2018; Rahayuningsih, 2020). Other research findings also state that animation can increase students' enthusiasm and motivation in learning, making it easier for students to understand learning materials (Amali et al., 2020; Endang Saripudin et al., 2018; Satyawan, 2018). Other research findings also state that learning animation videos can improve student learning outcomes (Inceday1, 2018; E Saripudin et al., 2018). It can be concluded that animation can help students in learning. The purpose of this research is to develop a powtoon-based animated video. It is hoped that the animated video based on powtoon can help improve students' critical thinking skills.

\section{METHOD}

This type of research is development (Research and Development). This research was conducted at SDN 66 Pekanbaru. The subjects of this study were third-grade students at SDN 66 Pekanbaru. Using a pre- 
experimental one group pretest posttest design. In this study, one experimental group was taken as a sample because this study only looked at the extent to which higher-order thinking skills were increased. The object of this research is video animation based on powtoon on high-order thinking skills of 3rd graders at SDN 66 Pekanbaru. The assessment of this powtoon-based animated video uses measurements using a Likert scale. This research design uses the ADDIE model. The ADDIE model has five stages, namely (1) Analyze (analyze). At the needs analysis stage, observation activities were carried out through interviews to determine the needs of learners and subject matter. (2) Design (Designing) at this stage, design the product and includes the material explained in the video and package in an attractive form. 3) Development at this stage is carried out to determine the validity of the product through expert tests, including material experts, media experts, and learning experts. After getting criticism and input from the validator, revisions were made according to expert suggestions. This was done prior to field trials. The media will be tested on 23 students and teachers to identify the practicality of the media through a questionnaire instrument. The media will be tested on the class used during the study. In this session, the evaluation results of higher-order thinking skills pre-test and post-test and presentation evaluation will be analyzed to ensure the effectiveness of learning media. Evaluation, this session is carried out through pretest and post-test data processing on thinking skills. High-level students use SPSS 20.0 for windows to do the Paired Sample t-test. The types of data obtained from this development are qualitative data and quantitative data. Qualitative data is used in the form of a questionnaire consisting of an evaluation questionnaire of media experts, learning materials experts, and language experts and quantitative data in the form of student evaluation scores.

There are three types of data collection techniques: a questionnaire filled out by teachers and students to identify their responses after viewing a portion-based animated video. Second, evaluation sheets are made to take into account the instruments and media created. Validation sheets are prepared based on the questionnaire format. This validation sheet is intended for media experts, material experts, and language experts. The third is a test that contains evaluations or exercises to be answered by students. This test was created to collect data on higher-order thinking skills. This study uses data analysis techniques, namely qualitative descriptive analysis techniques and quantitative descriptive analysis techniques. This qualitative descriptive analysis was made to find out the data from the review of material experts, language experts, and media experts in opinions and criticisms regarding the revision of Powton-based animated videos to improve higher-order thinking skills. Quantitative descriptive analysis that describes the results of the validity or practicality test of Powtoon-based animated videos on higher-order thinking skills. Quantitative descriptive analysis examines quantitative data in the form of numbers from the results of questionnaires or tests.

\section{RESULT AND DISCUSSION}

\section{Result}

In the needs analysis session, observations were made through interviews to find out the needs of teachers and students and the subject matter. Based on interviews with teachers. The teacher has never made a powtoon-based animated video media into a learning medium. The teacher still carries out the conventional learning process. Namely, the teacher explains orally, or and the students listen. In this session, the researcher also determines the theme of the objects around me and the sub-themes of various things around me on the material used by researchers in their research. In this session, the researcher also conducted interviews with students related to what kind of learning video media they like, namely video media that has characters such as moving animations and here the researcher also tries students to solve higher-order thinking questions, but students are still confused about the question given. In the design, the design of animated video media based on powtoon was carried out, the session carried out was opening the powtoon website and registering using email after having an account, the researcher took the next step, the researcher determined the background color, chose the animated character or image and chose the background that was already available in the powtoon. In addition, the activities carried out are adding photos and sounds other than those in Powtoon to be used in the development of learning media and presenting interesting material so that it is not monotonous, which will be developed into a Powtoon-based animated video media. Some of the images used are shown in the image below.

The picture above is part of a Powtoon-based animation video that has not been revised. In the image above, the 2nd media, the expert gives opinions and criticisms to change the color on the background to make it more concentrated, and media experts advise to minimize the writing on the video and use more animated images. Again. Based on the comments and suggestions of the media expert validator, the researcher revised the animation based on Powtoon. The picture above is part of an animated video that has been corrected according to the opinions and criticisms of media expert validators, using darker background color and minimizing text on the video, and using more animated images. 


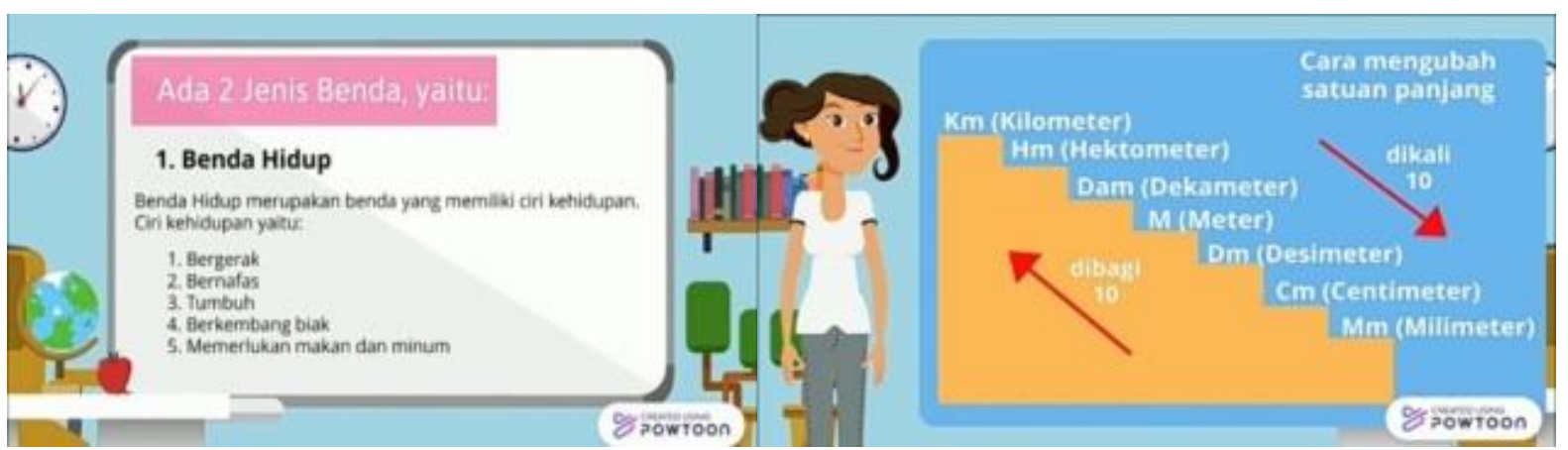

Figure 1.Before Revision

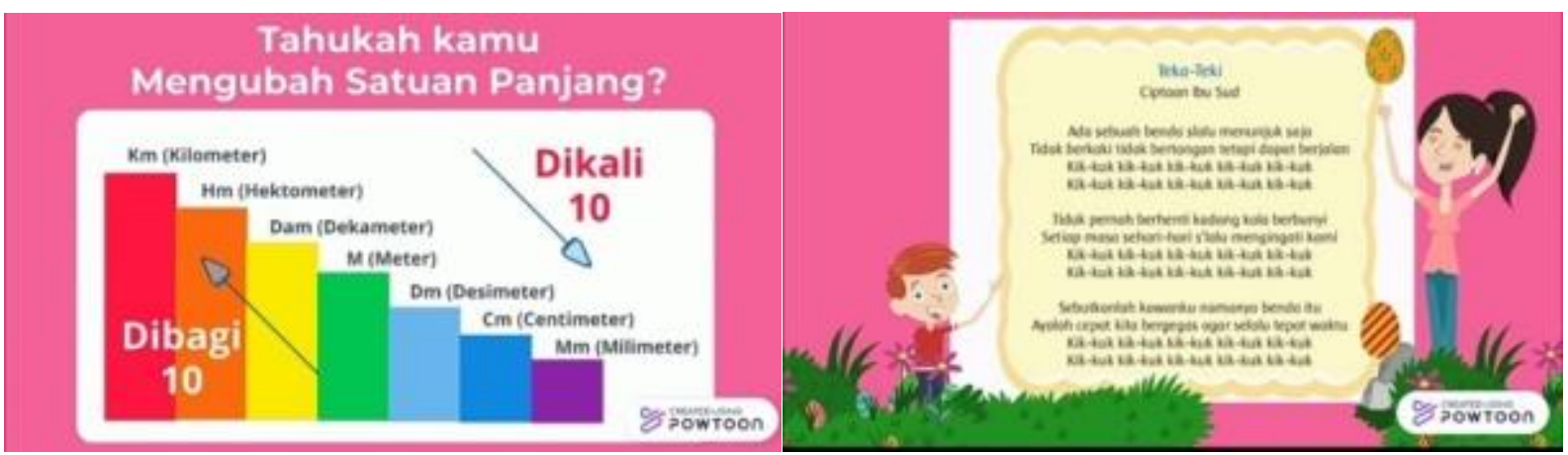

Figure 2. After revision

This development session was conducted by six validators, two media experts, two material experts, and two language experts. The following are the validation results from each validator in each area of expertise. In the aspect of material expert assessment, there is an educational aspect with a total of $94 \%$ categorized as very valid from the number of questionnaires filled out from two material experts. On the accuracy of the material with a total of $100 \%$ classified as very valid. The average score from the two content experts is $97 \%$, categorized as very valid with information suitable for use without revision. In the aspect of media experts, there are media aspects with a total of $97.5 \%$ classified as valid from the number of questionnaires filled out by two media experts. In the program display, a total of $92.5 \%$ is categorized as valid on the technical quality of the program, effectiveness with a total of $91.67 \%$. In total, the average values filled in from the two material experts is $94.67 \%$, categorized as very valid to use. Still, the second validator's criticisms or opinions for using dense background colors and minimizing writing in animation videos based on powtoon and more using animated images in powtoon-based animated videos. Based on the criticism or opinion of the validator, the two researchers revised the animation video media based on Powtoon with the results on the media aspect with a total of $100 \%$ categorized as very valid from the number of questionnaires filled out from two media experts. In the program view, a total of $97.5 \%$ is classified as very valid on the technical quality of the programeffectiveness with a total of $91.7 \%$. In total, the number filled in from two material experts, namely $96.7 \%$, is categorized as very valid. There is a specific assessment aspect in the language expert aspect, with $90 \%$ categorized as valid from the number of questionnaires filled out from two language experts. On the accuracy of the material and language rules with $8.5 \%$ categorized as very valid. On communicative with a total of $8.5 \%$ classified valid in conformity with the development of students with a total of $80 \%$ classified as valid. The consistency and integration of the flow of thought with $90 \%$ are categorized as valid. Incapacity, the number is filled in from material experts, which is $86.25 \%$ classified as valid with information suitable for use without revision.

In the media aspect with a total of $97 \%$ is categorized as very valid. In the material element, a total of $96.7 \%$ is classified as very valid. The aspect of language with a total of 86.25 is categorized as very valid. The total value of the validation of animation video media based on powtoon totality is $93.32 \%$, classified as very valid, so that this powtoon-based animated video media is very valid to be used. The students' responses regarding the animation video based on Powtoon on higher-order thinking skills. At the analyzing stage, $87.98 \%$ was categorized as very practical in evaluating the capacity obtained $89 \%$ was classified as very practical. At the creative scene, a total of $84.78 \%$ was classified as very practical. In total, the total number of 23 students, which is $87.25 \%$, is categorized as very practical. The results of the analysis of the teacher's response to the animation video based on Powtoon on higher-order thinking skills. In the aspect of program results with a total of $100 \%$ 
categorized as very practical. The effectiveness, with a total of $98.33 \%$, is classified as very practical. In total, the amount with a total of $99.33 \%$ is categorized as very practical. Based on the analysis of teacher and student responses, 93.29\% can be calculated by utilizing animation video media based on Powtoon, which is very practical to use. It can help students in higher-order thinking skills and is effectively used in the activities of the ongoing learning stages. Based on the high-level thinking skills presentation results, three people were categorized as high or $13 \%, 16$ as moderate or $70 \%$, and four as low or $17 \%$. In the evaluation session, the pretest and posttest data were processed using SPSS 20.0 for windows to try out the Paired Sample t-test. The step being tested is Analyze- Compare means- Paired Sample t-test. The results of hypothesis testing by researchers using a paired samples test between pretest and posttest (Pratika Surya \& Wahyudi, 2018). It is known that the difference between the pretest and posttest scores is 060.435 , where the total pretest score is 19.57. The total posttest score is 80.00 ; it can be seen from the $t$-value count is -48.195 with a significance of $0.00<0.005$, which means $\mathrm{H} 0$ is rejected, and Ha is accepted. So it can be concluded that there is a difference in the score of higher-order thinking skills before and after learning using animation video media based on Powtoon

\section{Discussion}

Media is a tool that teachers can use to process, capture, and convey information from one person to another who receives it so that students can easily understand the message (S. D. Laksana, 2017; Sukardi et al., 2020; I. Yusuf \& Widyaningsih, 2020). The use of learning media is to clarify the presentation of messages so that they are not too visual (Kamelia, 2019; Sholihin et al., 2020). The use of appropriate and varied educational media can overcome the passive attitude of students (Megawati \& Utami, 2020; Nurrohmah et al., 2018). In terms of educational media, it is useful to increase the excitement of learning, allowing students to learn on their own based on their interests and abilities (Budiarto et al., 2020; Lawrence \& Tar, 2018). Learning media also provide shared experiences for students about events in their environment (Imamah \& Susanti, 2021; Irfan Yusuf \& Widyaningsih, 2018). One of them is animated video media.

Animation can provide the same stimulation and can equate students' experiences and perceptions towards the content of the lesson. Learning that is presented with the help of animated videos will attract more students' attention to foster learning motivation (Amali et al., 2020; Megawati \& Utami, 2020; Satyawan, 2018). Teaching methods will be more varied, verbal communication through the teacher's words so that students do not get bored and teachers do not run out of energy (L. Lin \& Li, 2018). This animation concept illustrates the difficulty of presenting information in the form of an image, as well as a set of images (Rahayuningsih, 2020; E Saripudin et al., 2018). Animation allows a fixed or static object to move and look as if it is alive (Kolomuc et al., 2012). Multimedia animation forms motion from various media or things varied with effects and transition motion filters (Inceday1, 2018; Endang Saripudin et al., 2018). This makes students more enthusiastic about learning. The findings of previous studies also stated that animated videos could increase students' enthusiasm and motivation in learning (Megawati \& Utami, 2020; Satyawan, 2018). The findings of previous research also stated that animation could make it easier for students to understand learning material (L. Lin \& Li, 2018; Putra \& Sujana, 2020). Other research also states that animation can improve student learning outcomes (Lukman et al., 2019; Rahayuningsih, 2020). It can be concluded that energy helps students in learning. This research implies that the animated video developed can be used by teachers in teaching so that they can improve high-level thinking skills in third-grade elementary schools.

\section{CONCLUSION}

Animated video media get very good qualifications based on the total score from the experts. It can be concluded that the animated video media developed is suitable for use in the learning process. This animated video can make it easier for teachers to convey information to students and can improve students' higher-order thinking skills.

\section{REFERENCES}

Abdul Karim, Dini Savitri, \& Hasbullah. (2020). Pengembangan Media Pembelajaran Matematika Berbasis Android Di Kelas 4 Sekolah Dasar. Jurnal Lebesgue: Jurnal Ilmiah Pendidikan Matematika, Matematika Dan Statistika, 1(2), 63-75. https://doi.org/10.46306/lb.v1i2.17.

Acesta, A. (2020). Analisis Kemampuan Higher Order Thingking Skills (HOTS) Siswa Materi IPA Di Sekolah Dasar. Quagga: Jurnal Pendidikan Dan Biologi, 12(2), 170. https://doi.org/10.25134/quagga.v12i2.2831.

Almaiah, M. A., Al-Khasawneh, A., \& Althunibat, A. (2020). Exploring the critical challenges and factors influencing the E-learning system usage during COVID-19 pandemic. Education and Information Technologies, 25(6), 5261-5280. https://doi.org/10.1007/s10639-020-10219-y. 
Amali, L. N., Zees, N., \& Suhada, S. (2020). Motion Graphic Animation Video As Alternative Learning Media. Jambura Journal of Informatics, 2(1). https://doi.org/10.37905/jji.v2i1.4640.

Ani Rahmawati, Nur Lailatin Nisfah, S. K. (2019). The Capability Analysis of High Order Thinking Skills (HOTS) on Dynamic Electricity Material in Junior High School. JPPPF: Jurnal Penelitian Dan Pengembangan Pendidikan Fisika, 5(3). https://doi.org/10.21009/1.05211.

Anjarsari, E., Donny, D. F., \& Abdul, W. A. (2020). Pengembangan Media Audiovisual Powtoon pada Pembelajaran Matematika untuk Siswa Sekolah Dasar. Jurnal Matematika Dan Pendidikan Matematika, 2(2). https://doi.org/10.26594/jmpm.v5i2.2084.

Ariani, T. (2017). Pembelajaran Kooperatif Tipe Team Assisted Individualization (TAI): Dampak Terhadap Hasil Belajar Fisika Siswa. Jurnal Ilmiah Pendidikan Fisika Al-Biruni, 6(2), 169. https://doi.org/10.24042/jipfalbiruni.v6i2.1802.

Awalia, I., Pamungkas, \& Alamsyah. (2019). Pengembangan Media Pembelajaran Animasi Powtoon pada Mata Pelajaran Matematika di Kelas IV. Jurnal Matematika Kreatif-Inovatif, 10(1). https://doi.org/10.15294/kreano.v10i1.18534.

Awalia, Izomi, Pamungkas, A. S., \& Alamsyah, T. P. (2019). Pengembangan Media Pembelajaran Animasi Powtoon pada Mata Pelajaran Matematika di Kelas IV SD. Jurnal Matematika Kreatif-Inovatif, 10(1). https://doi.org/10.15294/kreano.v10i1.18534.

Bana, A. (2020). Students' Perception of Using the Internet to Develop Reading Habit. Jurnal of English Teaching, 6(1), 60-70. https://doi.org/10.33541/jet.v6i1.46.

Binali, T., Tsai, C.-C., \& Chang, H.-Y. (2021). University students' profiles of online learning and their relation to online metacognitive regulation and internet-specific epistemic justification. Computers \& Education, 175. https://doi.org/10.1016/j.compedu.2021.104315.

Budiarto, M. K., Joebagio, H., \& Sudiyanto, S. (2020). Student's View of Using Digital Learning Media in Classroom Activities: A Case of Public Senior High School in Cirebon, Indonesia. Jurnal Pendidikan Progresif, 10(1). https://doi.org/10.23960/jpp.v10.i1.202006.

Chalkiadaki, A. (2018). A systematic literature review of 21 st century skills and competencies in primary education. International Journal of Instruction, 11(3), 1-16. https://doi.org/10.12973/iji.2018.1131a.

Changwong, K., Sukkamart, A., \& Sisan, B. (2018). Critical thinking skill development: Analysis of a new learning management model for Thai high schools. Journal of International Studies, 11(2), 37-48. https://doi.org/10.14254/2071.

Gürsoy, G. (2021). Digital storytelling: Developing 21st century skills in science education. European Journal of Educational Research, 10(1), 97-113. https://doi.org/10.12973/EU-JER.10.1.97.

Hamzah, I., \& Mentari, S. (2017). Development of Accounting E-Module to Support the Scientific Approach of Students Grade X Vocational High School. Journal of Accounting and Business Education, 1(1), 78. https://doi.org/10.26675/jabe.v1i1.9751.

Hanif, M. (2020). The development and effectiveness of motion graphic animation videos to improve primary school students' sciences learning outcomes. International Journal of Instruction, 13(4), 247-266. https://doi.org/10.29333/iji.2020.13416a.

Harta, J., Rasuh, N. T., \& Seriang, A. (2020). Using HOTS-Based Chemistry National Exam Questions to Map the Analytical Abilities of Senior High School Students. Journal of Science Learning, 3(3), 143-148. https://doi.org/10.17509/jsl.v3i3.22387.

Hasbullah, H. (2018). Peningkatan Hasil Belajar Kognitif Biologi Menggunakan Model Problem Base Learning Berbasis Powtoon Siswa Kelas Xii Ipa 7 Sma N 1 Metro Semester Ganjil Tahun Pelajaran 2017/2018. BIOEDUKASI (Jurnal Pendidikan Biologi), 9(2), 124. https://doi.org/10.24127/bioedukasi.v9i2.1623.

Hobri, Septiawati, I., \& Prihandoko, A. C. (2018). High-order thinking skill in contextual teaching and learning of mathematics based on lesson study for learning community. International Journal of Engineering and Technology(UAE), 7(3), 1576-1580. https://doi.org/10.14419/ijet.v7i3.12110.

Ichsan, I. Z., Sigit, D. V., Miarsyah, M., Ali, A., Arif, W. P., \& Prayitno, T. A. (2019). HOTS-AEP: Higher order thinking skills from elementary to master students in environmental learning. European Journal of Educational Research, 8(4), 935-942. https://doi.org/10.12973/eu-jer.8.4.935.

Imamah, N., \& Susanti, L. Y. (2021). Development of Sigil-Based Additives and Addictive Substances Teaching Chart for Junior High School Students: Alternative Learning Resources During a Pandemic. INSECTA: Integrative Science Education and Teaching Activity Journal, 2(1), 15-30. https://doi.org/10.21154/insecta.v2i1.2464.

Inceday1, N. (2018). The Impact of Using Multimedia Technologies on Students Academic Achievement in the Bakirköy Final College. International Journal of Humanities, Social Sciences and Education, 5(1), 40-47. https://doi.org/10.20431/2349-0381.0501007.

Indah, P. (2020). Development of HOTS (High Order Thinking Skill) Oriented Learning Through Discovery Learning Model to Increase The Critical Thinking Skill of High School Students. International Journal of 
Chemistry Education Research, 3(3). https://doi.org/10.20885/ijcer.vol4.iss1.art4.

Kamelia, K. (2019). Using Video as Media of Teaching in English Language Classroom: Expressing Congratulation and Hopes. Utamax : Journal of Ultimate Research and Trends in Education, 1(1), 34-38. https://doi.org/10.31849/utamax.v1i1.2742.

Kamza, M., Husaini, \& Ayu, I. L. (2021). Jurnal Basicedu. Jurnal Basicedu, 5(5), 4120-4126. https://doi.org/10.31004/basicedu.v5i5.1347.

Khairunnisa, N. (2021). Penggunaan Aplikasi Videomaker Fx Dalam Pengembangan Media Pembelajaran Bahasa Indonesia. Jubindo: Jurnal Ilmu Pendidikan Bahasa Dan Sastra Indonesia, 5(3), $132-141$. https://doi.org/10.32938/jbi.v5i3.871.

Khan, F. M. A., \& Masood, M. (2015). The Effectiveness of an Interactive Multimedia Courseware with Cooperative Mastery Approach in Enhancing Higher Order Thinking Skills in Learning Cellular Respiration. Procedia - Social and Behavioral Sciences, 176, 977-984. https://doi.org/10.1016/j.sbspro.2015.01.567.

Kolomuc, A., Ozmen, H., Metin, M., \& Acisli, S. (2012). The Effect of Animation Enhanced Worksheets Prepared Based on 5E Model for the Grade 9 Students on Alternative Conceptions of Physical and Chemical Changes. Procedia - Social and Behavioral Sciences, 46. https://doi.org/10.1016/j.sbspro.2012.05.374.

Koning, B. B. de, Marcus, N., Brucker, B., \& Ayres, P. (2019). Does observing hand actions in animations and static graphics differentially affect learning of hand-manipulative tasks? Computers \& Education, 41. https://doi.org/10.1016/j.compedu.2019.103636.

Kühl, T. (2021). Prerequisite knowledge and time of testing in learning with animations and static pictures: Evidence for the expertise reversal effect. Learning and Instruction, 73. https://doi.org/10.1016/j.learninstruc.2021.101457.

Laksana, D. N. L. (2020). Implementation of Online Learning in The Pandemic Covid-19: Student Perception in Areas with Minimum Internet Access. Journal of Education Technology, 4(4), 509-509. https://doi.org/10.23887/jet.v4i4.29314.

Laksana, S. D. (2017). Improving The Quality Of Learning Mathematics Through Innovative Learning Media. Jurnal Pendidikan Dan Pengajaran, 50(2). https://doi.org/10.23887/jpp.v50i2.11658.

Lawrence, J. E., \& Tar, U. A. (2018). Factors that influence teachers' adoption and integration of ICT in teaching/learning process. Educational Media International, 55(1), 79-105. https://doi.org/10.1080/09523987.2018.1439712.

Lestari, N. dwi, Hermawan, R., \& Heryanto, D. (2018). Pengembangan Media Pembelajaran Menggunakan Powtoon Untuk Pembelajaran Tematik Sekolah Dasar. Jurnal Pendidikan Guru Sekolah Dasar, 3(3), 3343. https://doi.org/10.17509/jpgsd.v3i3.20748.

Lin, H., \& Chen, T. (2016). Decreasing cognitive load for novice EFL learners: Effects of question and descriptive advance organizers in facilitating EFL learners' comprehension of an animation-based content lesson. System, 34(3). https://doi.org/10.1016/j.system.2006.04.008.

Lin, L., \& Li, M. (2018). Optimizing learning from animation: Examining the impact of biofeedback. Learning and Instruction, 55. https://doi.org/10.1016/j.learninstruc.2018.02.005.

Lu, H. P., \& Wang, S. M. (2008). The role of Internet addiction in online game loyalty: An exploratory study. Internet Research, 18(5), 499-519. https://doi.org/10.1108/10662240810912756.

Lukman, A., Hayati, D. K., \& Hakim, N. (2019). Pengembangan Video Animasi Berbasis Kearifan Lokal pada Pembelajaran IPA Kelas V di Sekolah Dasar. Elementary: Jurnal Ilmiah Pendidikan Dasar, 5(2), 153. https://doi.org/10.32332/elementary.v5i2.1750.

Megawati, \& Utami. (2020). English Learning with Powtoon Animation Video. Journal of Education Technology, 4(2), 110. https://doi.org/10.23887/jet.v4i2.25096.

Mershad, K., \& Wakim, P. (2018). A Learning Management System Enhanced with Internet of Things Applications. Journal of Education and Learning, 7(3), 23. https://doi.org/10.5539/jel.v7n3p23.

Nurrohmah, F., Putra, F. G., \& Farida, F. (2018). Development of Sparkol Video Scribe Assisted Learning Media. Formatif: Jurnal Ilmiah Pendidikan MIPA, 8(3), 233-250. https://doi.org/10.30998/formatif.v8i3.2613.

Nuswowati, M., Susilaningsih, E., Ramlawati, \& Kadarwati, S. (2017). Implementation of problem-based learning with green chemistry vision to improve creative thinking skill and students' creative actions. Jurnal Pendidikan IPA Indonesia, 6(2), 221-228. https://doi.org/10.15294/jpii.v6i2.9467.

Perdana, Sarwanto, Sukarmin, S., \& Sujadi, I. (2017). Development of E-Module Combining Science Process Skills And Dynamics Motion Material To Increasing Critical Thinking Skills And Improve Student Learning Motivation Senior High School. International Journal of Science and Applied Science, 1(1), 4554. https://doi.org/10.20961/ijsascs.v1i1.5112.

Pratika Surya, J., \& Wahyudi, I. (2018). Implementation of the Stem Learning To Improve the Creative Thinking 
Skills of High School Student in the Newton Law of Gravity Material. Journal of Komodo Science Education, 01(01), 106-116.

Putra, I. G. D., \& Sujana. (2020). Hasil belajar IPS menggunakan Kolaborasi Model Discovery Learning Berbasis Media Animasi. Journal of Educational Technology, 4, 103-109. https://doi.org/10.23887/jet.v4i2.25099.

Rahayuningsih, S. (2020). Animation media of animal husbandry thematic science learning to stimulate scientific attitude in early childhood. International Journal of Scientific and Technology Research. https://doi.org/10.23887/jet.v3i1.17959 Article Metrics.

Ratajczak, M. (2018). Language and value: the philosophy of language in the post-Operaist critique of contemporary capitalism. Language Sciences, 17. https://doi.org/10.1016/j.langsci.2018.08.004.

Rosalina, S. S., \& Suhardi, A. (2020). Need Analysis of Interactive Multimedia Development With Contextual Approach on Pollution Material. INSECTA: Integrative Science Education and Teaching Activity Journal, 1(1), 93. https://doi.org/10.21154/insecta.v1i1.2107.

Samsudin, A., Kelana, J. B., \& Muftianti, A. (2019). Utilization of Internet-Based Learning Media in Enhancing Science Literacy Capabilities of Pgsd Students. PrimaryEdu - Journal of Primary Education, 3(2), 91. https://doi.org/10.22460/pej.v3i2.1284.

Sanchez, C. A., \& Weber, K. (2019). Using Relevant Animations to Counter Stereotype Threat When Learning Science. Journal of Applied Research in Memory and Cognition, 8(4). https://doi.org/10.1016/j.jarmac.2019.08.003.

Sapeni, M. A.-A. R., \& Said, S. (2020). The effectiveness of case-based learning in increasing critical thinking of nursing students: A literature review. Enfermería Clínica, 30(2). https://doi.org/10.1016/j.enfcli.2019.07.073.

Sari, Hindun, Mahmudati, Miharja, \& Fauzi. (2020). Are Male and Female Students Different in High-Order Thinking Skills? Jurnal Pendidikan Indonesia, 9(1), 42-48. https://doi.org/10.23887/jpiundiksha.v9i1.17575.

Saripudin, E, Sari, I., \& Mukhtar, M. (2018). Using Macro Flash Animation Media on Motion Material to Improve Learning Achievement for Learning Science in Junior High School. , 4 (1),. Journal of Science Research and Learning, 4(1), 68-75. https://doi.org/10.30870/jppi.v4i1.3316.

Saripudin, Endang, Sari, I. J., \& Mukhtar, M. (2018). Using Macro Flash Animation Media on Motion Material to Improve Learning Achievement for Learning Science in Junior High School. Jurnal Penelitian Dan Pembelajaran IPA, 4(1), 68-75. https://doi.org/10.30870/jppi.v4i1.3316.

Satyawan, V. (2018). The Use Of Animation Video To Teach English At Junior High School Students. Jellt (Journal of English Language and Language Teaching), 2(2), 89-96. https://doi.org/10.36597/jellt.v2i2.3277.

Sholihin, M., Sari, R. C., Yuniarti, N., \& Ilyana, S. (2020). A new way of teaching business ethics: The evaluation of virtual reality-based learning media. The International Journal of Management Education, 18(3). https://doi.org/10.1016/j.ijme.2020.100428.

Sugianti, L., -, S., \& Marhaeni, A. A. I. . (2018). Pengaruh Model Pembelajaran Berbasis Masalah Terhadap Kemampuan Berpikir Tingkat Tinggi Dan Kemampuan Menanya Dalam Pembelajaran Matematika Kelas V Sd. PENDASI: Jurnal Pendidikan Dasar Indonesia, 2(1), 35-46. https://doi.org/10.23887/jpdi.v2i1.2691.

Sugiarto, A. (2020). Dampak Positif Pembelajaran Online Dalam Sistem Pendidikan Keperawatan Pasca Pandemi Covid 19. Jurnal Perawat Indonesia, 4(3), 432. https://doi.org/10.32584/jpi.v4i3.555.

Sukardi, Mayefis, R., \& Usmeldi. (2020). Effectiveness of Mobile Learning Media on Computer Assembly at Vocational High School Effectiveness of Mobile Learning Media on Computer Assembly at Vocational High School. Journal of Physics: Conference Series, 1-6. https://doi.org/10.1088/17426596/1594/1/012012.

Turan, M. B., \& Koç, K. (2018). The impact of self-directed learning readiness on critical thinking and selfefficacy among the students of the school of physical education and sports. International Journal of Higher Education, 7(6), 98-105. https://doi.org/10.5430/ijhe.v7n6p98.

Wartono, W., Hudha, M. N., \& Batlolona, J. R. (2018). How are the physics critical thinking skills of the students taught by using inquiry-discovery through empirical and theorethical overview? Eurasia Journal of Mathematics, Science and Technology Education, 14(2), 691-697. https://doi.org/10.12973/ejmste/80632.

Wulandari, Y. (2020). Pengembangan Media Video Berbasis Powtoon pada Mata Pelajaran IPA di Kelas V. Jurnal Pendidikan Sains Indonesia (Indonesian Journal of Science Education), 8(2). https://doi.org/10.24815/jpsi.v8i2.16835.

Yusuf, I., \& Widyaningsih, S. W. (2020). Implementing e-learning-based virtual laboratory media to students' metacognitive skills. International Journal of Emerging Technologies in Learning, 15(5). 
https://doi.org/10.3991/ijet.v15i05.12029.

Yusuf, Irfan, \& Widyaningsih, S. W. (2018). Implementasi Pembelajaran Fisika Berbasis Laboratorium Virtual terhadap Keterampilan Proses Sains dan Persepsi Mahasiswa. Berkala Ilmiah Pendidikan Fisika, 6(1), 18. https://doi.org/10.20527/bipf.v6i1.4378.

Zhang, J., Liao, G., \& Li, N. (2020). Combining active learning and local patch alignment for data-driven facial animation with fine-grained local detail. Neurocomputing, 39. https://doi.org/10.1016/j.neucom.2019.05.102.

Zulfiani, Suwarna, I. P., \& Sumantri, M. F. (2020). Science adaptive assessment tool: Kolb's learning style profile and student's higher order thinking skill level. Jurnal Pendidikan IPA Indonesia, 9(2), 194-207. https://doi.org/10.15294/jpii.v9i2.23840. 